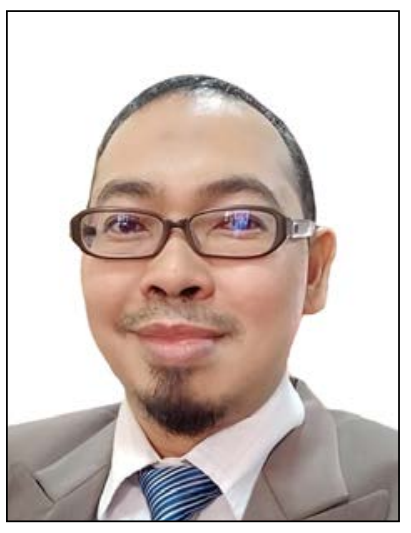

Bintoro Rahadi Wasi,

Lecturer, Faculty of Law,

Jenderal Soedirman University,

Indonesia, Grendeng-Purwokerto

e-mail: rahadi.bintoro@unsoed.ac.id

doi: 10.21564/2414-990X.153.222847

UDC 341

\title{
BASIC PRINCIPLES OF SHARIA ECONOMY FOR COMMUNITY ECONOMIC EMPOWERMENT (STUDY OF THE SHARIA PRINCIPLES APPLICATION IN INDONESIA)
}

Islamic financial institutions tend to no longer apply profit and loss sharing but more to revenue sharing. On the other hand, the Sharia economy aims to empower people to fulfill human needs based on Islamic values to achieve happiness in the world and end. Therefore, the focus of this paper is the application of Sharia principles in the sharia economy. The research method to answer the legal issue is normative legal research that is analyzed qualitatively. Sharia financial institutions are still unable to escape from their existence as business institutions for the main purpose of profiting. This is certainly far from the spirit of empowerment of people in the sharia economy. Islamic financial institutions should not be separated from the core of the sharia economy, namely the empowerment of people. Therefore, Sharia financial institutions must utilize social corporate responsibility to achieve the objectives of community empowerment.

Keywords: sharia economy; community economic empowerment; Indonesia.

Бінторо P. B., викладач кафедри процесуального права, юридичний факультет, Університет імені генерала Судірмана, Індонезія, м. Гренденг-Пурвокетто.

e-mail: rahadi.bintoro@unsoed.ac.id

Основні принципи шаріатської економіки для економічного розвитку громади (аналіз застосування принципів шаріату в Індонезіi)

Ісламські фінансові установи, як правило, вже не застосовують розподіл прибутку і збитків, а в основному різні ставки по відношенню до доходів. 3 іншого боку, шаріатська економіка спрямована на розширення прав і можливостей людей для задоволення людських потреб, заснованих на ісламських иінностях, досягнення щастя та успіху. Тому метою нашого дослідження є аналіз застосування принщипів шаріату в шаріатській економіці. Метод дослідження для відповіді на юридичне питання є нормативним юридичним дослідженням. Установи шаріату, як і раніше, не можуть уникнути свого існування як комерційних, основною метою яких є отримання прибутку.

(C) Bintoro R. W., 2021 
Це, безумовно, далеко від духу розширення прав і можливостей людей у шаріатській економіці. Ісламські фінансові установи не мають бути відокремлені від ядра шаріатської економіки, що має на меті розширення прав $і$ можливостей людей. Тому вони повинні використовувати соціальну корпоративну відповідальність для досягнення цілей розширення прав і можливостей громад.

Ключові слова: шаріатська економіка; розширення економічних прав і можливостей громад; Індонезія.

Formulation of the problem. The world economic system can basically be qualified into the liberal economic system, the socialist economic system and the Islamic economic system [1]. In the liberal and socialist economic system, industry players compete to collect assets and produce as much production as possible. The community began to move seporadis to meet the needs of each individual's life which then resulted in a moral turmoil resulting from the fulfillment of their respective lives. Wealth and wealth are no longer a source of peace, but rather turn into a source of moral illness that needs to be addressed [2].

Responding to the development of the economic system, Sayyid Qutub argued that:

"this country of mass production, immense wealth and easy pleasures. I have seen them [Americans] a helpless prey in the clutches of nervous diseases in spite of all their grand appearances ... They are like machines swirling round madly, aimlessly into the unknown ... That they produce a lot there is no doubt. But to what aim is this mad rush? For the mere aim of gaining and production. The human element has no place if their life is neglected ... Their life is an everlasting windmill which grinds all in its way: men, things, places and time ... What is the medicine to all this imbroglio? A peaceful heart, a serene soul, the pleasure which follows strenuous work, the relation of affection between men, the cooperation of friends" [2].

Both economic systems were initially seen as able to provide maximum benefits to the community, but in reality on the ground emerged the adverse effects of the system. This condition then encourages economists to study the sharia economy which has actually developed for a long time in the Muslim community in the world.

The Islamic economic system again gained attention in the early 1970s [3]. This islamic economic development emerged as a result of criticism of the existing economic system at the time [4], namely the capitalist economic system and socialist economic system that ignores the importance of social welfare resulting in development is only felt by certain circles. Sharia economic development is currently in line with the theory of benefit, that Islam through sharia exists to bring benefits. Sharia is intended as a provision established by God and explained by His Messenger about the actions of man, in achieving a good life in the world and the hereafter. If this is related to the term law, then the law in Islamic law itself, in general, can stand alone. The law can be interpreted as a set of rules concerning acts of conduct, or conduct, recognized by a country or society, applicable and binding on all its members, if the understanding is connected with Islam or syara', then Islamic law will mean a set of rules based on the revelation of God and the Sunnah of the Messenger of Allah concerning human behavior mukallaf recognized and believed to 
apply and binding to all who are Muslims [5]. Term islamic law, thus encompassing the understanding of the law syara' and law figh, because the meaning of syara' and fiqh are include inside.

Islamic law is elastic. The elasticity of Islamic law is very adaptive to the dynamics of social change and the progress of the times. This is because of the multidimensional nature in the scope of Islamic law covers all aspects of human life. The purpose of the establishment of Islamic law is to realize the benefit of mankind [6].

Sharia economy is an integral unity with the comprehensive and universal teachings of Islam, its broad and flexible nature and scope, especially in the field of mu'amalah, so it is not surprising that sharia economy can be applied to every community including non-Muslims [7].

Islamic finance in Indonesia has grown over two decades since the operation of Bank Muamalat Indonesia, as the first Sharia bank in Indonesia. Sharia economic development has resulted in various achievements, from the increasing number of products and services to the development of infrastructure that supports Islamic finance, even in the global market, Indonesia is among the top ten countries that have the largest Islamic financial index in the world, this is based on Roadmap of Financial Indonesia Sharia 2017-2024.

Rapid islamic economic growth [8], was not accompanied by the readiness of Sharia economic infrastructure in understanding and applying Sharia principles, so some researchers [9] the view that Sharia economic practices, especially in banking institutions, are not in accordance with sharia principles.

In practice, Islamic financial institutions tend to no longer apply profit and loss sharing but more to reveneu sharing. On the other hand, Sharia economy aims to empower people to fulfill human needs based on Islamic values to achieve happiness in the world and end. Therefore, the focus of this paper is the application of Sharia principles in sharia economy.

The analysis of the recent researches and publications. This paper is a part of legal research and to answer the problem, the approach method used is a concept and legislation approach. Therefore, the primary source of legal material is the legislation relating to the object of this study, they are Law relating on Sharia banking and it is supported by secondary legal materials, in the form of literature for instance books and scientific journals. After the source of legal material is collected, then qualitative analysis is conducted by describing the data quality in the form of a regular, coherent, logical, non-overlapping and effective sentence, thus it is facilitating the interpretation of the data.

\section{A. DISCUSSION}

1. Essence of Sharia Economy

Economic terminology comes from the Greek, oikos (household) and nomos (rule of law) [10], while Sharia means rules based on Islamic law. S. M. Hasanuzzaman defines sharia economy as a knowledge and application of sharia teachings and rules that prevent injustice in the search and exploration of various resources, to provide 
birth and mental satisfaction for human beings and enable them to carry out all their obligations to Sang Kholiq and society [11]. According to Muhammad Abdul Mannan, sharia economics is a social science that studies economic problems from people who have Islamic values [12]. Khursid Ahmad defines Islamic economics as a systematic effort to try to understand economic problems and human behavior in relation to the problem from an Islamic point of view [13]. According to M. N. Siddiqi sharia economics is the response of Muslim thinkers to economic challenges in their lifetime, the main source of the Qur'an and as-Sunnah as well as reason and experience [13]. According to M. Akram Khan sharia economics aims to study human welfare (falah) achieved by organizing the earth's resources on the basis of cooperation and participation [13]. According to Louis Cantori, sharia economics is nothing but an attempt to formulate human-oriented and community-oriented economics that rejects the excesses of individualism in classical economics [13]. According to Munawar Iqbal, the Sharia economy is a discipline that becomes an offshoot of Islamic shari'a. Revelation, from an Islamic perspective, is seen as the main source of science and technology (mamba'ul'ilmi). Then the Qur'an and al-hadith are used as a source of reference to assess new theories based on Islamic economic doctrines [14]. Based on this understanding, it can be concluded temporarily that sharia economy is a human activity in order to fulfill its needs, whose procedures, objectives and rules are always based on sharia, as a form of human piety to Allah SWT.

Sharia economy is an economic activity and practice carried out as an effort to fulfill people's lives. Human beings always and must coexist with other human beings, because human beings can not meet all kinds of complex needs with their own efforts, but also need the intervention of others in fulfilling their lives [15]. The fulfillment of the event is an economic motive that underlies various changes in behavior in society. The purpose of fulfilling human life is to achieve happiness (Al Farabi), of course without providing disruption to other individuals, so that it needs a community order [15]. The order of society must be in accordance with and derived from the rules of Prima Causa which is considered as the source of origin of the entire universe and all laws contained in it. As the universe is hierarchically governed by Prima Causa, society also needs similar arrangements, lifting people based on their position in society [15].

According to the Islamic worldview, the happiness of life that should be achieved by man is happiness in this world and in the Hereafter. Therefore, the economic motives used in the economy are also an order to achieve happiness in the world and the hereafter. Therefore, in the implementation of the Islamic economic system is always based on revelation and has a connection with the laws of figh. The economic system developed by Muslim philosophers is also the description of the science of fiqh [16] that is related to muamalah.

Based on some opinions, some think that sharia economy emerged as a reaction to the conventional economic system that is rampant in various Islamic countries. There are also those who argue that sharia economy is a product of the thinking of 
Muslim scholars and thinkers who formulate the procedures of peace in the field of economics in accordance with sharia principles [17]. Sharia economy, according to historical view, is a side effect of the efforts of philosophers, fuqaha, and scholars who seek to contribute thought in regulating the order of society in terms of governance, social and ethics based on sharia guidance [18] the purpose of the order is the realization of the fulfillment of justice between members of society as a whole both rights and obligations in accordance with the teachings of Islam.

Sharia economic system is not only aimed at regulating the management of property, but also social relations between individuals in an effort to meet their economic needs. Charles Trip points out that:

"...that property must be used for a higher end, suchas the sustenance and support of those in a less fortunate position than yourself; the idea of mutual social responsibility which ensures the integration of the individual into a truly Islamic society" [19].

Based on these social objectives, wealth ownership in Islam is not only intended as an individual interest. There is a noble value contained from the ownership of inter-individual property. Human property, assets and resources must be used for the purpose of maintaining, not only to take care of the owner of the property personally, but also to secure social stability and integrity in society. That is why wealth is not only seen as an object of fulfillment of needs, a measuring scale of satisfaction and happiness. Wealth is also seen as a subject in determining social relationships full of a sense of responsibility. Furthermore, this concept is considered as a form of social security system. The concept is used in sharia economy with the aim of ensuring the welfare of society through a sense of responsibility and social balance [20].

Islamic law is elastic. The elasticity of Islamic law is very adaptive to the dynamics of social change and the progress of the times. This is because, multidimensional nature in the scope of Islamic law covers all aspects of human life. The purpose of the establishment of Islamic law is to realize the benefit for mankind [21].

He is the All-knower, the All-knower. Allah is All-Judged, All-Knower. Mashlahah's theory comes from the theory of Islamic law whose orientation of the shot is more than emphasizing the element of benefit or benefit to man rather than questioning mere normative problems. This theory does not merely look at the sound of the legal text (the sound of verses of the Quran and hadith) nor the written law, but rather focus on the principles of rejecting harm in order to maintain the purposes of syara'. Imam Al-Ghazali considers that a benefit must be in line with the purpose of syara', even if it is contrary to human purposes because the human benefit is not always based on the will of syara'. Human beings in relationship with others is none other than to realize the benefits for human beings in all aspects and aspects of life in the world and avoid various forms that can lead to damage, in other words, every provision of the law that has been outlined by the sharia' is aimed at creating benefit for mankind [22].

Sharia economic system in which is based on the guidance of the Qur'an and As-Sunnah, is a system that will bring the ummah of man to the path that is didhoi 
by Allah Swt. This system is based on Islam, because Islam as a «mercy lil alamin» that is mercy for the universe, has the meaning of Islam not only for the Ummah of Islam, but also for all His creatures on the earth. In the Islamic economic system there are three foundations in its application, namely tawhid, aqidah, and sharia [23]. Tauhid, meaning that this economic system is based on only one goal, namely achieving His keridhoan in every economic activity that has been carried out on various sides of this life. Aqidah, which means that this economic system guarantees all economic actors contained in it must have a good and correct aqidah so that there is no injustice or injustice in every economic activity carried out. Shariah means that this economic system must be based on sharia guidance (Qur'an and As-Sunnah) that applies in every economic activity carried out. Surely when it has been fulfilled the three foundations of the Islamic economic system will eventually bring benefits to all human beings on the face of the earth.

Sharia economy is implemented with the aim of [24]:

a. Economic well-being within the framework of Islamic moral norms (based on QS. Al-Baqarah verse 2 and 168, Al-Maidah verse 87-88, Al-Jumu'ah verse 10);

b. Forming a society with a solid social order based on universal justice and fraternity (QS. Al-Hujuraat verse 13, Al-Maidah verse 8, Asy-Syu'araa verse 183);

c. Achieve a fair and equitable distribution of income and wealth (QS. Al-An'aam verse 165, An-Nahl verse 71, Az-Zukhruf verse 32); dan

d. Creating individual freedom in the context of social welfare (QS.Ar-Ra'du verse 36, Luqman verse 22).

Sharia economy which is part of the economic system, has values that focus on 'amar ma'ruf and nahi mungkar (ordering/doing the right and leaving the prohibited), so that sharia economy can be seen from four points of view as follows [25]: First, the Llahiyah Economy (godhead). The divine economy means that man was created by God to fulfill His commandments, namely worship, and in seeking his life's needs, man must be based on the rules (sharia) with the main purpose of obtaining God's pleasure; Second, the economy of morality. Moral economy means that the unity between economy and morality must be related to the production, distribution, and consumer sectors. Thus, a Muslim does not do anything desirable or profitable regardless of others; Third, the economy of humanity. The economy of humanity means God predicates the "caliph" only to man because man is given the ability and feel that allows him to carry out his duties. Through its role as the "caliph" of human beings must do charity, work hard, create, and innovate; and Fourth, Economic balance. Economic equity balance is An Islamic view of the rights of individuals and communities placed in a balance of justice about the world and the hereafter, body, and soul, reason and heart, parables and reality, faith and power.

2. Basic Principles of Sharia Economy in Financial Institutions

Thus the Islamic economy, because it not only aims to get profit/profit on only one party, but also bring benefits to other parties, including the community. Therefore, it is not surprising, if sharia economy is considered more humane than the capitalist and socialist economic system. Moreover, Sharia economy is not only 
pursuing worldly aspects, but also ukhrowi. Sharia economy is then expanded in the system of financial institutions, especially banking which later became known as Sharia banking. Seeing the stretch of society, especially the Muslim community, banks are competing by providing banking facilities that apply Sharia principles.

Sharia economics is an emergence in the Islamic world in the 20th century by Muslim intellectuals to fight the hegemony of conventional Western-style economy. Sharia economy is a form of application of Sharia values in community interaction related to ownership and equity of property based on the Quran and Hadith as a form of piety and faith. The rise of sharia economy is an effort of Muslims to escape from the economic system that is not in accordance with sharia principles. therefore, the scholars and fuqaha transformed the fiqhiyyah rules into the joints of social sciences of society that developed following the changing times. The economic system developed by Muslim philosophers is the description of fiqh science related to interaction between individuals (muamalah). Thus, the foundation underlying sharia economy is the product of the thought of fiqh laws related to muamalah.

The rise of the Islamic economic system has developed Islamic financial institutions. Modern Islamic financial institutions talk about mark-up instruments (such as murabahah and ijarah) and Profit and Loss Sharing (such as Mudharabah and musyarakah) [26] which is the basic concept of economic products managed by Islamic financial institutions. The basic concept that underlies economic products in Islamic financial institutions (banks and non-banks) must always be based on islamic sources and norms contained in Islamic teachings. The reference of transactions that are the root of transaction practices in Islamic finance is $b a^{\prime} i$, ijarah, grant, and ariyah.

The basic principles of the law are laid down in the four root transactions of (1) sales (bay), transfer of the ownership or corpus of property for a consideration; (2) hire (ijsra), transfer of the usufruct (right to use) of property for a consideration; (3) gift (hiba), gratuitous transfer of the corpus of property; and (4) loan (ariyah), gratuitous transfer of the usufruct of property. These basic principles are then applied to the various specific transactions of, for example, pledge, deposit, guarantee, agency, assignment, land tenancy, waqf foundations (religious or charitable bodies) and partnerships, which play an important role in Islamic financing and form the backbone of Islamic banking practices [27].

Economic practices carried out by Islamic financial institutions are part of the practices contained in a more comprehensive Islamic economic system. Not only does it rely on profit-oriented, but Islamic financial institutions also have a role as a social security system. Sources and norms contained in Islamic financial institutions must certainly be in line with the sources and norms contained in the Islamic economic system. Wahyu Illahi is the source of the law in Islam and is a way of life for every Muslim. His teachings are more guiding and directing so that his teachings can always be accommodated in every socioeconomic phenomenon that have occurred in society. The Islamic economic system is always based on the revelation of Illahi which is the guideline for the life of every Muslim. In divine revelation contained 
the rule of law which is referred to as sharia. Sharia law is the way of life for every Muslim in terms of economy, social, and religion.

The rapid development of the national and international economy, accompanied by broader challenges, must always be followed responsively by national banks in carrying out their functions and responsibilities to the community. Law No. 14 of 1967 and several other laws in the banking sector that are in force to date, have been unable to keep up with the development of the national economy and internationally, resulting in the enactment of Law No. 7 of 1992. The provision of Article 5 Paragraph (1) of Law No. 7 of 1992 outlines that according to its type the bank consists of Commercial Banks and People's Credit Banks. Based on this law, steps are initiated to accommodate and provide a legal basis for sharia banks that have been formed to start running. Law No. 7 of 1992, does not explicitly mention the existence of so-called «Sharia Banks». There are only two that can be used as the basis, namely Article 6 letter $(\mathrm{m})$ relating to the scope of general banking and Article 13 letter (e) relating to one of the scopes of activities of the People's Credit Bank with the same content mentioning «Providing financing for customers based on the principle of yield-share following the provisions stipulated in government regulations».

The term used in this law is thus «Bank Based on The Principle of Fruit Share». Article 6 letter (m) and Article 13 letter (e) have not provided much further arrangement regarding what is meant by the principle term for profit-share itself, its operational legal basis, and what business activities can be operationalized and implemented by the bank. However, it should be underlined here, the birth of Law No. 7 of 1992 is a step forward from the struggle of all parties because there are other alternatives in the world of banking other than conventional banks, namely banks based on the principle of for-money share.[28] Such reality, provides great hope that fosters optimism for all of us to continue to strive to develop sharia economy in Indonesia.

Furthermore, on October 30, 1992, Government Regulation No. 72/1992 (Statute Book No. 119) on Banks based on The Principle of Yield Share was established. Article 1 Paragraph (1) specifies that "a bank based on the principle of profit-making is a Commercial Bank or a People's Credit Bank conducting business activities solely based on the principle of profit-making". The article explained that "what is meant by the principle of for-like results in this government regulation is "muamalat principle based on Sharia" in conducting bank business activities. From the word "muamalat principle based on Sharia". This then changed to based on "Sharia principles" and briefly called "Sharia Bank" or "Sharia Banking". Sharia banks or banks based on Sharia principles, therefore formally, began to be introduced in Government Regulation No. 72 of 1992 [29].

After the enactment of Law No. 7 of 1992, in 1998 has been passed Law No. 10 of 1998 on amendments to Law No. 7 of 1992 on Banking (Statute Book No. 182 of 1998, Supplement to Statute Book No. 3790, hereinafter referred to as Law No. 10 of 1998). At this level, the regulation on Sharia Banking which was once only referred 
to as «bank based on the profit-share principle», now in the law has been clearly stated using the term «Bank Based on Sharia Principles». As described in Article 1 Paragraph (3) of Law No. 10 of 1998, among others states that «Commercial Bank is a bank that carries out business activities conventionally and/or based on Sharia principles». While Paragraph (4) states that «People's Credit Bank is a bank that carries out activities conventionally or based on Sharia principles». Sharia principles referred to in this law are described in Article 1 number 13 of Law No. 10 of 1998, namely the rules of the agreement under Islamic law between banks and other parties for the deposit of funds and or financing of business activities, or other activities declared following Sharia.

The birth of Law No. 23 of 1999 concerning Bank Indonesia (Statute Book No. 66 of 1999, Supplement to Statute Book No. 3843, hereinafter referred to as Law No. 23 of 1999), which has now been amended by Law No. 3 of 2004 concerning Amendment to Law no. 23/1999 concerning Bank Indonesia (Statute Book of 2004 Number 7, Additional Statute Book No. 4357, hereinafter referred to as Law No. 3 of 2004), has contained several specific provisions relating to the existence and development of Sharia Banking in the country. In Article 10 of Law No. 23 of 1999 concerning monetary control issues, Bank Indonesia has been given the mandate to implement it based on Sharia Principles. Then for Sharia Banks to operate optimally and to complete the rule of law on the operation of Sharia Banks, law No. 21 of 2008 on Sharia Banking (Government Gazette No. 94 of 1992, Supplement to Statute Book No. 4867, hereinafter referred to as Law No. 21 of 2008) on July 16, 2008. Thus, the banking system in Indonesia adheres to a dual banking system. The dual banking system is the implementation of two banking systems (conventional and sharia) side by side [30].

According to Law No. 21 of 2008 to be categorized in the Islamic economic sphere, it is determined by the MUI fatwa. MUI as an institution that has authority in the field of religion and related to the interests of Indonesian Muslims, established the National Sharia Council (DSN). DSN is intended to handle problems related to the activities of Islamic Financial Institutions (LKS). While the Sharia Supervisory Board (DPS) is an existing body in the LKS and is tasked with overseeing the implementation of DSN decisions in the LKS.

The thought for the establishment of DSN was first proposed at the Alim Ulama workshop held on 29-31 July 1997 in Jakarta. The reason for the establishment of DSN in the workshop, in addition to forming an institution that can integrate and coordinate each DPS contained in each LKS, as well as supervise all LKS activities, so as not to deviate from sharia provisions. Also, the establishment of DSN is expected to be able to answer various financial and economic problems where operationalization and settlement require the involvement of Sharia law [31].

DSN MUI institution was finally officially established on February 10, 1999, in accordance with the Decree (SK) MUI Number kep-754 / MUI / II / 1999. The strong authority owned by this institution is the determination and safeguard of sharia principles in operations in LKS such as Sharia banking, Sharia insurance, 
Sharia reinsurance, Sharia mutual funds, Sharia bonds and Sharia securities, Sharia financing, Sharia securities, and others. This is because LKS or other Sharia business activities have special characteristics that are different from the management of financial institutions or conventional business activities. One interesting thing about the proliferation of business activities with Sharia principles is the pattern of resolving disputes related to the authority of the Religious Court. As stipulated in Law No. 3 of 2006 concerning Amendment to Law No. 7 of 1989 concerning Religious Justice Article 49 stipulates that the Court of Religion is authorized to examine and decide disputes about sharia economy.

DSN-MUI is an institution that has authority in issuing fatwas related to various forms of Products of Islamic Financial Institutions, especially Sharia Banks. Initially, Bank Indonesia in setting regulations on Sharia banking must first refer to the fatwa issued by the DSN MUI, but the functions, duties, and authorities of regulation and supervision of financial services activities in the Banking sector, since December 31, 2013, switched from Bank Indonesia to the Financial Services Authority. The Regulation of the Financial Services Authority in Sharia banking must therefore refer to the fatwa issued by the DSN MUI. This indicates that the institution is independent and has authority in terms of sharia in this case DSN MUI. The daily activities of the National Sharia Council are carried out by the Daily Implementing Agency with a chairman and secretary as well as several members.[32]

DSN-MUI was formed by majelis Ulama Indonesia (MUI) which has the function of carrying out mui duties in dealing with problems related to the activities of Islamic financial institutions. One of the main tasks of DSN is to review, explore and formulate the values and principles of Islamic law in the form of fatwas to be used as guidelines in transaction activities in Islamic financial institutions.

Provision of Article 26 paragraph (2) of Law No. 21 of 2008 stipulates that: "Sharia Principles as referred to in paragraph (1) shall be declared by the Indonesian Ulama Council". Then in paragraph (3) formulate that "Fatwa as intended in paragraph (2) shall be stated in Bank Indonesia Regulation". Thus, it is clear the position of the DSN MUI, where the fatwa issued by the DSN-MUI is not a positive law, just like the fatwas issued by the MUI in other fields, but nevertheless the fatwas issued by the DSN-MUI can apply and bind [33] as applicable positive law in Indonesia, when followed up as a Regulation of the Financial Services Authority. Therefore, the activities of Islamic financial institutions should not be contrary to sharia principles, issued through the DSN-MUI fatwa and converted into a Regulation of the Financial Services Authority. According to Sutan Remi Sjahdeini [34], sharia principles for the sake of law have acted as positive law, even if it has not or is not set forth in the Regulation of the Financial Services Authority. Thus, although the fatwa has not been applications in the regulation, it still has the force of law, so it must be obeyed by every financial institution that uses the Sharia system.

Some principles commonly used in Sharia banking include: Some principles commonly used in Sharia banking include: First, Community Fund Collection Products, including Sharia Demand Deposits, i.e. deposits whose withdrawals can 
be made at any time by using cheques / bilyet giro, other means of payment orders, or by book-entry. Giro Syariah is carried out on the principles of Wadiah and Mudharabah. Sharia savings accounts, i.e. deposits whose withdrawals can only be made according to certain conditions agreed, but cannot be withdrawn by cheque/ bilyet giro, and or other tools equated with it. This saving is done on the principle of Wadiah and Mudharabah. Sharia deposits, namely: deposits whose withdrawals can only be made at a certain time based on an agreement between the customer and the bank, conducted under the Mudharabah principle. Second, banking products in the form of disbursement of funds to the community, there are several principles used, namely; Mudharabah Financing, Musyarakah Financing, Murabahah Financing, Salam Financing, Istishna Financing, Qardh Financing. Third, service products. Service products in syarian banking include: Letter of Credit (L/C Syariah-L/C importer), namely Understanding the statement letter will pay to the Exporter (beneficiary) issued by the Bank (issuing bank) at the request of the Importer with the fulfillment of certain requirements (Uniform Customs and Practice for documentary Credits / UCP), which is carried out with akad Wakalah bil Ujrah and Kafalah. Sharia Guarantee Bank, which is a guarantee given by the bank to third parties of the collateral recipient for the fulfillment of certain obligations of bank customers as a guaranteed party to the third party in question, which is carried out by the principle of kafalah agreement. Transfer and Inkaso, namely transfer and Inkaso is a service provided by the bank to represent the customer in the transfer of funds from the customer's account (transfer) or to collect for the profit of the customer's account (inkaso), which is carried out on the principle of wakalah. Sharia pledges, i.e. the delivery of goods as collateral to obtain debts. That was done by the agreement of Rahn, Qardh, and Ijarah.

In practice, Islamic Financial Institutions, especially those engaged in financing, such as Islamic banking, tend to prioritize the use of murabahah principles. June 2015 Akad Mudharabah 14,906 7.31 \% Akad Musyarakah 54,033 26.50\% Akad Murabahah 117,777 57.76 \% Akad Salam 00.00 \% Akad Murabahah 117,777 57.76 \% Akad Salam 00.00 \% Akad Istishna 6780.33 \% Akad Ijarah 11,561 5.67 \% Akad Qardh 4.9382 .42 \% Total 203,894 100 \% (Processed SPS 2015 Data). The data shows the dominant murabahah principle in financing. This is inseparable from the view that the risk of applying this principle is relatively low.

The application of this principle shows that Sharia banking still cannot relinquish itself as a business entity with a purpose for profit. Of course, if it is linked to the objectives of Sharia economic principles, this will be very contrary, because the objective of sharia economy is not only beneficial to one party, especially Islamic financial institutions, but also to benefit all of them. The application of Sharia principles is not only attached to the use of contracts in legal relations but must reach the core of sharia economic objectives. Sharia's economy has a passion to empower the economy of the people.

In order to provide balance to the existence of Islamic financial institutions, on the one hand, the fact shows that the dominant «profit» is the ultimate goal, 
then financial institutions should also not forget the social responsibility to the environment (social corporate responsibility). The practice of social corporate responsibility in Islamic financial institutions, in fact, is inseparable from the religious spirit that becomes guidance for the development of Islamic financial institutions themselves. Justice is the core in social relations as stipulated in the Qur'an and exemplified by the Messenger of Allah.

The dominance of profit as the objective of Islamic financial institutions is very contrary to the philosophy of sharia kuangan institutions that encourage to operate on moral, ethical, and social responsibility grounds. Thus, Islamic financial institutions should also prioritize social corporate responsibility in their operations.

From the analysis above, can be concluded that the application of Sharia economic principles in economic activities is a necessity of the community to uphold Sharia in the lives of Muslims. This is done as a form of obedience and piety to Allah Swt. Sharia Economic Principles applied by financial institutions, especially banks in Indonesia have been carried out. However, Sharia banking institutions still cannot escape from their existence as business institutions for the main purpose of profiting. This is certainly far from the spirit of empowerment of people in sharia economy.

There is a suggestion to looking forward of this research, in order to provide balance to the existence of Islamic financial institutions, on the one hand as a business institution, financial institutions should also not forget social corporate responsibility. The application of Social corporate responsibility will certainly bring benefits to the wider community, because Islamic financial institutions in the end not only act as business institutions, but also financial institutions can really empower people, as is the philosophy of Sharia Economy.

This paper is part of the research that has been carried out by the author. On this occasion, the author expressed his gratitude to the Institute for Research and Community Service (LPPM) Of Universitas Jenderal Soedirman (Unsoed)who has been pleased to give the opportunity to the author to conduct this research through the Institutional Research scheme with funding from BLU Unsoed.

\section{References}

1. Muslim, M.B. (2012). Perbandingan Ekonomi Islam dan Ekonomi Kapitalis. Al Iqtishad, 4 (2).

2. Trip, C. (2006). Islam and the Moral Economy. USA: Cambridge University Press.

3. Asutay, M. (2007). Conceptualisation of the Second Best Solution in Overcoming the Social Failure of Islamic Banking and Finance: Examining the Overpowering of Homoislamicus by Homoeconomicus. IIUM Journal of Economics and Managemen, 15 (2); The International Islamic University Malaysia; M. Raquibuz Zaman and Hormoz Movassaghi. (2001). Islamic Banking a Performance Analysis. The Journal of Global Business, 12 (22); Abd. Shomad. (2010). Penerapan prinsip Bagi hasil pada Bank Syariah di jawa Timur. Masalah-masalah Hukum, 39 (2).

4. Presley, J.R and John G Sessions. (1994). slamic Economics: The Emergence of a New Paradm. The Economic Joumal, 104, May. URL: http://www.jstor.org/discover/10.2307/2234633?sid=2110524 2446221\&uid=2\&uid=3738224\&uid=4, on December 11, 2014.

5. Syarifuddin, A. (2008). Ushul Fiqih, Jilid I, ctk. Ketiga, Jakarta: Kencana Prenada Media Group.

6. Shomad, A. Rekonstruksi Akad Bank Syariah Untuk Mencapai Kemaslahatan sebagai Wujud Rahmatan Lil Alamin. Inaugural speech of The Position of Professor in Sharia Business Law at the Faculty of Law, Airlangga University in Surabaya on June 1, 2013. 
7. Ahmad. Penyelesaian Sengketa Ekonomi Syariah di Pengadilan Agama. Jurnal Ius, 2 (6).

8. Iqbal, M. and Philip Molyneux. (2006). Thirty Years Of Islamic Banking:History, Performance And Prospects. J.Kau: Islamic Econ., 19 (1); M. Kabir Hassan and Abdel-Hameed M. Bashir. (2003). Determinants of Islamic Banking Profitability. Papers, 10th ERF Annual Conference, Morocco, URL: http://nzibo.com/IB2/Determinants. pdf, diakses pada tanggal 11 Desember 2014; Mardani. Kedudukan Hukum Islam dalam Sistem hukum Nasional. Jurnal Hukum, 16 (2).

9. Zaman, M.R. and Hormoz Movassaghi. (2001). Islamic Banking A Performance Analysis. The Journal of Global Business, 12 (22); Feisal Khan. (2010). How 'Islamic' is Islamic Banking? Journal of Economic Behavior \& Organization, 76 (3); Mohammed Khaled I. Bader, Shamsher Mohamad And Mohamed Ariff. (2008). Cost, Revenue, And Profit Efficiency Of Islamic Versus Conventional Banks: International Evidence Using Data Envelopment Analysis. Islamic Economic Studies, 15 (2).

10. Putong, I. (2010). Economics Pengantar Mikro dan Makro. Jakarta: Mitra Wacana Media.

11. Rahardjo, M.D. (1999). Islam dan Transformasi Sosial Ekonomi. Yogyakarta: Pustaka Pelajar.

12. Mannan, A. and Muhammad. (1993). Ekonomi Islam Teori dan Praktek Dasar-dasar Ekonomi Islam. Yogyakarta: Dana Bhakti Wakaf.

13. Chapra, U. (2001). Masa Depan Ekonomi, Sebuah Tinjauan Islam. Jakarta: Gema Insani Press.

14. Sudarsono, H. (2002). Konsep Ekonomi Islam: Suatu Pengantar. Yogyakarta: Ekonisia.

15. Poli, W. (2010), Tonggak-Tonggak Sejarah Pemikiran Ekonomi. Surabaya: Brilian Internasional.

16. Usanti, T.P and Abdul Shomad. (2016). Reconstruction of Financing Agreement Based on the Principle of Profit and Loss in Sharia Banking. Hasanuddin Law review, 2 (1).

17. Abd. Shomad. (2012). Konsep Lembaga Bank Jaminan di Lingkungan Bank Syariah. Yuridika, $23(3)$.

18. Ahmed and Rodney Wilson El-Ashker. (2006). Islamic Eceonomics: A Short History, Netherland: Brill.

19. Trip, C. (2006). Islam and the Moral Economy. USA:Cambridge University Press.

20. As-Shadr, M.B. (1982). Iqtishaduna (Our Economics), Jilid II. Teheran: World Organization for Islamic Service.

21. Shomad, A. (2013). Rekonstruksi Akad Bank Syariah Untuk Mencapai Kemaslahatan sebagai Wujud Rahmatan Lil Alamin. Inaugural speech of the Position of Professor in Sharia Business Law at the Faculty of Law, Airlangga University in Surabaya on June 1, 2013.

22. Romli, SA. (1999). Muqaranah Mazahib Fil Usul, Jakarta: Gaya Media Pratama.

23. Baraba, A. (1999). Prinsip Dasar Operasional Perbankan Syariah. Buletin of Monetary Economics and Banking, 2 (3).

24. Ismanto, K. (2011). Pengelolaan Lembaga Keuangan Syari'ah Berbasis Total Quality Management. Religia, 14 (1); Maskur Rosyid. (2015). Dimensi Kemanusiaan Dalam Sistem Ekonomi Islam (Sebuah Kajian dengan Pendekatan Filsafat Hukum Islam). Khazanah, Jurnal Studi Islam dan Humaniora, 13 (1); Anita Rahmawaty. (2013). Distribusi Dalam Ekonomi Islam-Upaya Pemerataan Kesejahteraan Melalui Keadilan Distributif. Equilibrium, 1 (1).

25. Mardani, (2011). "Hukum Ekonomi Syariah di Indonesia”. Bandung: Refika Aditama.

26. Sramek, O. (2009). Islamic Economics: New Economic Paradigm, or Political Agenda? New Perspective on Political Economy, 5 (2009). h. 137-167.

27. Lewis, M.K. (2007). Handbook of Islamic Banking. USA: Edward Elgar Publishing.

28. Usanti, T.P. (2012). "Pengelolaan Risiko Pembiayaan di Bank Syariah. Adil, 3 (2).

29. Rahmi, D. (2013). Ruang Lingkup Kewenangan Peradilan Agama Dalam Mengadili Sengketa Ekonomi Syariah. Syariah-Jurnal Ilmu Hukum, 13 (2).

30. Usanti, T.P and Abd. Shomad. (2015). Hukum Perbankan. Surabaya: Kerjasama Fakultas Hukum Universitas Airlangga dan Lutfansah Mediatama.

31. Anshori, A.G. (2008). Aspek Hukum Reksa Dana Syariah di Indonesia. Bandung: Refika Aditama.

32. Antonio, M.S. (2001). Bank Syariah dari Teori ke Praktik. Cet. 1. Jakarta: Gema Insani Press.

33. Usanti, T.P. (2013). Absorbsi Hukum Islam pada Akad Pembiayaan di Bank Syariah. Surabaya: Lutfansah Mediatama. 
34. Sjahdeini, S.R. (2010). Perbankan Syariah Produk-produk dan Aspek Hukumnya. Jakarta: Jakarta Agung Offset.

Бинторо P. B., преподаватель кафедры процессуального права, юридический факультет, Университет имени генерала Судирмана, Индонезия, г. Гренденг-Пурвокетто.

e-mail: rahadi.bintoro@unsoed.ac.id

Основные принципы шариатской экономики для экономического развития сообщества (анализ применения принципов шариата в Индонезии)

Исламские финансовые учреждения, как правило, уже не применяют распределение прибыли и убытков, а в основном разные ставки по отношению к доходам. С другой стороны, шариатская экономика направлена на расширение прав и возможностей людей для удовлетворения человеческих потребностей, основанных на исламских ценностях, достижения счастья и успеха. Поэтому целью нашего иследования является анализ применения принципов шариата в шариатской экономике. Метод исследования для ответа на юридический вопрос является нормативным юридическим исследованием. Уиреждения шариата по-прежнему не могут избежать своего существования в качестве коммерческих, основной челью которых является получение прибыли. Это, безусловно, далеко от духа расширения прав и возможностей людей в шариатской экономике. Исламские финансовые учреждения не должны быть отделены от ядра шариатской экономики, а именно расширения прав и возможностей людей. Поэтому они должнь использовать социальную корпоративную ответственность для достижения целей расширения прав и возможностей общин.

Ключевые слова: шариатская экономика; расширение экономических прав и возможностей общин; Индонезия.

Рекомендоване цитування: Bintoro R. W. Basic principles of sharia economy for community economic empowerment (study of the sharia principles application in Indonesia). Проблеми законноcmi. 2021. Вип. 153. С. 199-212. doi: https://doi.org/10.21564/2414-990X.153.222847.

Suggested Citation: Bintoro, R.W. (2021). Basic principles of sharia economy for community economic empowerment (study of the sharia principles application in Indonesia). Problemy zakonnosti - Problems of Legality, issue 153, 199-212. doi: https://doi.org/10.21564/2414-990X.153.222847.

Надійшла до редколегї 18.12.2020 p. 